Przegląd Prawa Konstytucyjnego

----ISSN 2082-1212-----

DOI 10.15804/ppk.2021.06.42

-----2021, No. 6 (64)-----

\title{
Paulina Ura ${ }^{1}$
}

\section{The Constitutional Right to Appeal Against an Administrative Decision}

Keywords: appeal, appeal procedure, the principle of two instances, constitutional guarantees

Słowa kluczowe: odwołanie, postępowanie odwoławcze, zasadna dwuinstancyjności, gwarancje konstytucyjne

\begin{abstract}
The article aims to draw attention to such an administrative procedure in which a citizen's right to control administrative decisions issued by an administrative authority is guaranteed. This control is carried out mainly in the course of an instance examination of a case. The analysis of solutions in this respect against the background of constitutional guarantees will allow for the answer of whether legal solutions guarantee the right of an individual to hear an administrative case. The analysis of these solutions is based on the jurisprudence of the Constitutional Tribunal and administrative courts and the views contained in the literature.
\end{abstract}

\section{Streszczenie}

\section{Konstytucyjne prawo do wniesienia odwołania od decyzji administracyjnej}

Celem artykułu jest zwrócenie uwagi na takie ukształtowanie procedury administracyjnej, w której zagwarantowane zostało prawo człowieka i obywatela do kontroli wydawa-

1 ORCID ID: 0000-0001-6665-5761, Ph.D., Department of Administrative Law and Administrative Procedure, Institute of Legal Studies, College of Social Sciences, University of Rzeszow.E-mail: urapaulina@op.pl. 
nych przez organ administracji decyzji administracyjnych. Kontrola ta prowadzona jest przede wszystkim w toku instancyjnego badania sprawy. Analiza rozwiązań w tym zakresie na tle konstytucyjnych gwarancji pozwoli na odpowiedź czy rozwiązania prawne gwarantują prawa jednostki do rozpoznania sprawy administracyjnej.

Analiza powyższych rozwiązań dokonana zostanie na tle orzecznictwa Trybunału Konstytucyjnego oraz sądów administracyjnych, a także poglądów zawartych w literaturze.

An appeal against an administrative decision is a means of appeal, triggering the administrative course of the instance (apart from a complaint). Appealing against the decision of the first instance authority is classified as ordinary and relatively devolutive legal measures, resulting in postponing the appeal's examination to a higher-level authority only if the first instance authority refuses to take them into account ${ }^{2}$. The right of appeal is one of the fundamental rights guaranteed to the party (parties) to administrative proceedings in the Polish Constitution, which expresses the general principle that all decisions may be challenged in any legal proceedings, aimed at preventing mistakes and arbitrariness of issued judgments and decisions. Stressing the importance of the right guaranteed in the Art. 78 of the Constitution, the Constitutional Tribunal has so far stated that the right to challenge judgments is an important element of procedural fairness ${ }^{3}$. The right of appeal has also been specified in one of the general principles of administrative proceedings, which is the principle of two-instance proceedings.

\section{The Right to Appeal Against Judgments in the Light of the Constitution of the Republic of Poland}

Article 78 of the Constitution of the Republic of Poland states: "Each party has the right to appeal against judgments and decisions issued in the first in-

2 B. Adamiak, [in:] Kodeks postępowania administracyjnego. Komentarz, eds. B. Adamiak, J. Borkowski, Warsaw 2019, p. 723.

3 Judgment of the Constitutional Tribunal, November 13, 2018, file ref. Act SK 17/17. 
stance. The law specifies the exceptions to this rule and the procedure for appealing against them. The law may be applied to judgments and decisions issued only in the first instance, which implies that the Constitution adopts the principle of two-instance proceedings ${ }^{4}$.

The scope of application of the term "appeal" used in Art. 78 of the Constitution covers not only administrative proceedings in which the decision on the rights of a party takes place in a procedure reflecting the administrative and legal relations between the entity issuing the decisions (the deciding entity) and the party, but also other proceedings conducted by public authorities in order to consider individual cases of an individual and other entities of private law ${ }^{5}$. Thus, the interpretation of the constitutional concept of an "appeal" has substantive limits.

From the first sentence of the Art. 78 of the Constitution, it is possible to derive a postulate addressed to the legislator that the procedure should be shaped to provide for the right of a party to appeal. The essence of the law under analysis includes initiating the verification of the decision or judgment made in the first instance, which creates the perspective of controlling the first decision and thus preventing arbitrariness and the consolidation of mistakes ${ }^{6}$. Therefore, the legislator is obliged not only to provide a party with the right to appeal against a judgment or decisions issued in the first instance but also to enable the body examining the appeal to make a substantive assessment of the correctness of the settled case.

Appealing against a judgment leads to its verification and issuing a new one, which may be confirmed by the act issued in the first instance or revoked or amended. As a rule, the appeal measure should be suspensive, even if the execution of the decision does not lead to causing further damage unless the legitimate interests of another private entity or the need to protect vital public interests warrant this. However, it does not have to be devolutive and does

W. Skrzydło, Konstytucja Rzeczypospolitej Polskiej. Komentarz do art. 78, LEX 2013, https://sip.lex.pl/\#/commentary/587434060/428331/skrzydlo-wieslaw-konstytucja-rzeczy pospolitej-polskiej-komentarz-wyd-vii?cm=URELATIONS (3.01.2021).

5 Judgment of the Constitutional Tribunal of March 14, 2006, file ref. SK 4/05, OTK ZU, No. 3/A/2006, item. 29.

6 Judgment of the Constitutional Tribunal on June 12, 2002, sygn. P 13/01, OTK ZU, No. 4/A/2002, item. 42. 
not have to lead to the examination of the case by an authority of the same type but occupying a higher place in the structure of the state apparatus?

Article 78 of the Constitution - on the one hand - provides that each party has the right to appeal against judgments and decisions issued in the first instance, and on the other hand - authorizes the legislator to define exceptions to this principle and the procedure for appealing against. While the Art. 78 guarantees the general right to appeal against decisions issued in the first instance in all proceedings conducted by public authorities, in so far as the Art. $176 \mathrm{sec} .1$ formulates the principle of two-instance court proceedings, applicable in cases heard from the beginning to the end by the courts 8

Article $176 \mathrm{sec} .1$ of the Constitution should be interpreted in conjunction with other constitutional provisions specifying the rights of an individual, in particular in conjunction with the Art. 78 of the Constitution, containing the "general expression of the principle of two-instance procedures", relating to all procedures (including out-of-court procedures) in which judgments or decisions in individual cases are made. Article 78 of the Constitution establishes a subjective right (for the benefit of "everyone"), subject to protection in the constitutional complaint procedure, but not of an absolute nature, allowing the legislator to define exceptions to the two-instance principle. On the other hand, the Art. $176 \mathrm{sec}$. 1 of the Constitution also excludes exceptions to court proceedings. It has "intrinsic legal significance", specifying and completing the general principle contained in the Art. 78 of the Constitution. "Article 176 sec. 1 of the Constitution is, therefore, an element constituting the right of" everyone "to the second instance, so it should also be considered in terms of provisions regulating the rights of an individual".

\section{Verification of Administrative Decisions}

The content of the Art. 78 is - in the most general sense - establishing the right of the parties to each proceeding to initiate the procedure verifying the

7 K. Wojtyczek, Prawo do skutecznego środka prawnego w Konstytucji RP, "Przegląd Konstytucyjny” 2017, No. 1, pp. 84-85.

8 Judgment of the Constitutional Tribunal of March 27, 2007, file ref. SK 3/05.

9 Judgment of the Constitutional Tribunal of November 13, 2018, file ref. SK 3/05. 
correctness of any individual decisions issued by the body acting as the first instance $^{10}$. In the administrative procedure, the rule resulting from this provision is expressed in one of the general rules of procedure contained in Art. 15 of the Code of Administrative Procedure and in specific provisions contained in chapter 10, section II of the Code.

Under Art. 15 of the Code, the administrative procedure is two-instance unless a specific provision provides otherwise. Thus, the principle of two-instance administrative proceedings means that a party (or another authorized entity) may appeal against each decision issued in the first instance to a public administration body of a higher degree than the body that issued the decision under appeal ${ }^{11}$. The essence of the principle of two-instance administrative proceedings consists in double examination and settlement by two different organs of the same case determined by the content of the challenged decision $^{12}$. As stated by the Provincial Administrative Court in Warsaw, the general principle of two-instance administrative proceedings (Art. 15 of the Code), having the value of a constitutional principle (Art. 78 of the Constitution), imposes an obligation on a higher-level authority to reconsider and adjudicate in its entirety. However, in case of a change in the legal status that occurs between the issuance of the decision of the first instance authority and the review of the appeal (application for reconsideration of the case) by the competent authority, the two-instance principle obliges the authority to consider the case and issue a decision considering new or amended provisions. One guiding principle of administrative proceedings is actions taken by the authorities under the legal provisions (Art. 6 of the Code), so the authorities are always obliged to take into account the change in the legal status that occurs in the course of the proceedings and adjudicate based on the provisions in force at the date of the decision. It does not mean that the authorities adjudicate based on new or amended provisions in each case because a differ-

10 A. Błaś, [in:] Konstytucje Rzeczypospolitej oraz komentarz do Konstytucji RP z 1997 roku, ed. J. Boć, Wrocław 1998, p. 140.

11 Z. Kmiecik, Dwuinstancyjność ogólnego postępowania administracyjnego w świetle przepisów Konstytucji RP i Kodeksu postępowania administracyjnego, "Annales Universitatis Mariae Curie-Skłodowska, Sectio G”2017, vol. LXIV, p. 92.

12 Judgment of the Provincial Administrative Court in Warsaw dated September 20, 2016, file ref. II SA/Wa 24/16, LEX No. 2137451. 
ent way of applying the provisions may result from the relevant intertemporal norms ${ }^{13}$.

\section{Limitation of the Principle of Two Instances}

The principle of two instances is somewhat limited in the provision of the Art. $127 \$ 3$, which stipulates that the decision issued in the first instance by the minister or the local government board of appeal may not be appealed against. However, a party dissatisfied with the decision may request this body to reconsider the case (Art. $127 \$ 3$ ). This solution is justified by organizational reasons, as the structure of the public administration apparatus does not provide for a higher authority than the minister and the local government appeals board. At the same time, it should be emphasized that the Art. $127 \S 3$ must always be interpreted in conjunction with special provisions that may provide for the admissibility of an appeal against a decision issued by a minister within the meaning of the Code of Administrative Procedure ${ }^{14}$.

In case of a silent settlement, the Code's provisions do not provide for expressis verbis an appeal against this form of settlement by appeal, which should be treated as an exception to the principle of two-instance administrative proceedings, unless the appeal provided for in the Art. 122f $\$ 2$ of the Code, a complaint against the decision to issue a certificate of silent settlement of the case or the decision to refuse to issue such a certificate. In the justification of the draft amendment, it is stated that "the silent settlement of the matter as a special way of resolving it is not subject to appeal under the general rules of the Code of Administrative Procedure, nor by way of a complaint to an administrative court. In this case, we are not dealing with a decision or any other act or action that could become the subject of appeal proceedings or review by an administrative court"15.

13 Judgment of the Provincial Administrative Court in Warsaw of December 4, 2018, file ref. I SA/Wa 935/18, LEX No. 2629216.

14 B. Majchrzak, Weryfikacja rozstrzygnięć w toku instancji, [in:] Postępowanie administracyjne, eds. W. Federczyk, M. Klimaszewski, B. Majchrzak, Warsaw 2013, p. 197.

15 A. Wróbel, Komentarz do art. 15, [in:] Kodeks postępowania administracyjnego. Komentarz aktualizowany, eds. M. Jaśkowska, M. Wilbrandt-Gotowicz, A. Wróbel, LEX/el. 2020, https:// 
According to the Art. $127 \S 1$ of the Code, the appeal may be against the administrative decision issued in the first instance. Therefore, if the action taken by the authority does not constitute this form of action (i.e., a decision), then it is not subject to appeal, and if it is brought, it must be declared inadmissible. The letter of the authority from which the appeal was lodged does not have such features, does not settle any matter, and is only informative ${ }^{16}$. The reasons for the inadmissibility of a subject appeal also include the legal non-existence of the subject of the appeal, i.e., the non-existence of an administrative decision in the legal sense, in a situation where the challenged act of the authority is not a decision but a material and technical act. According to the content of the Art. $127 \$ 1$ of the Code, an appeal may only be made against an administrative decision ${ }^{17}$.

The principle of two instances implies the fundamental right of a party to appeal against any non-final decision. The right to appeal against any non-final decision should be treated in the state ruled by law as a public subjective right of a citizen ${ }^{18}$.

\section{Appeal Proceedings}

The right to appeal covers both a preliminary decision issued in ordinary proceedings, the subject of which is to determine a party's material-law rights or obligations, and an incomplete decision issued in extraordinary proceedings, aimed at verifying a decision issued in ordinary proceedings ${ }^{19}$.

The appeal procedure is based on the principle of complaints; therefore, it may not be initiated ex officio under any circumstances. It may be initiated primarily by the party.

sip.lex.pl/\#/commentary/587260105/633058/jaskowska-malgorzata-wilbrandt-gotowicz-m artyna-wrobel-andrzej-kodeks-postepowania...? $\mathrm{cm}=$ URELATIONS (3.01.2021).

16 Judgment of the Provincial Administrative Court in Rzeszów of April 2, 2020, file ref. II SA/Rz 89/20, LEX No. 3031141.

17 Judgment of the Provincial Administrative Court in Poznań of March 5, 2020, file ref. II SA/Po 691/19, LEX No. 3007216.

18 H. Knysiak-Molczyk, Uprawnienia strony w postępowaniu administracyjnym, Zakamycze 2004, https://sip.lex.pl/\#/monograph/369140925/162987/knysiak-molczyk-hanna-uprawni enia-strony-w-postepowaniu-administracyjnym?cm=URELATIONS (4.01.2021).

19 B. Majchrzak, op.cit., p. 196. 
The right to appeal is also vested in entities with party rights: social organizations, prosecutors, Ombudsmen for Children, and Civil Rights. Despite considerable fluctuations in the doctrine and - as it may be assumed the resulting divergences in the judicial and administrative jurisprudence, the dominant view at present seems to be that this right depends on the participation of a social organization, a prosecutor, and other entities that obtained this status under special provisions before the authority of the first instance ${ }^{20}$.

In the provision of the Art. $127 \$ 2$ of the Code, the principle was formulated that the appeal body (competent to consider the appeal) is the body of a higher rank than the body which issued the appealed decision. However, it contains a reservation that the law may provide for a different appeal body ${ }^{21}$.

The Code of Administrative Procedure adopts an indirect appeal procedure. According to the Art. $129 \$ 1$ of this Code, the appeal is submitted to the competent appeal body through the body that issued the decision. The indirect procedure of appealing is primarily related to its relative devolution. Therefore if the appeal is lodged directly with the competent appeal body (higher-level body), it should be transferred to the body that issued the decision in the first instance, through a material and technical $\mathrm{act}^{22}$. The appeal is transferred under Art. $65 \$ 1$ of the Code of Administrative Procedure, whether a party should be notified.

The appeal shall be lodged within fourteen days from the date of notification of the decision to the party and when the decision was announced orally from the date of its announcement to the party. Nevertheless, special provisions may provide for different deadlines for lodging an appeal. The deadline

20 Z. Kmieciak, Komentarz do art. 127, [in:] Kodeks postępowania administracyjnego. Komentarz, eds. W. Chróścielewski, Z. Kmieciak, https://sip.lex.pl/\#/commentary/587785975/583415/ chroscielewski-wojciech-red-kmieciak-zbigniew-red-kodeks-postepowania-administracyjnegokomentarz?cm=URELATIONS (4.01.2021).

21 Z. Kmieciak, Odwołania w postępowaniu administracyjnym, Oficyna 2011, https://sip. lex.pl/\#/monograph/369223521/159507/kmieciak-zbigniew-odwolania-w-postepowaniuadministracyjnym?cm=URELATIONS (14.01.2021).

22 H. Knysiak-Molczyk, Czynności procesowe zawodowego petnomocnika $w$ sprawach administracyjnych i sądowoadministracyjnych, LexisNexis 2013, https://sip.lex.pl/\#/monograph/369305641/239381/knysiak-molczyk-hanna-red-czynnosci-procesowe-zawodoweg o-pelnomocnika-w-sprawach...?cm=URELATIONS (14.01.2021). 
for appealing is a due date on which the party must act. It is strictly defined, statutory, and rigid, so appealing after the deadline is ineffective ${ }^{23}$.

The decision is not enforceable before the expiry of the appeal period. Filing an appeal on time suspends the execution of the decision, except in cases where the decision has been made immediately enforceable (Art. 108) or the decision is immediately enforceable under the Act. The decision shall be enforced before the expiry of the appeal period if it complies with the request of all parties or if all parties have waived their right to appeal.

After an appeal has been lodged with the appeal body through the body that issued the appealed decision, the appeal procedure begins, consisting of two stages:

- appeal proceedings before the first instance authority;

- appeal proceedings before the second instance authority.

The stage of the proceedings before the first instance authority begins with notifying the parties of the appeal. Under the Art. 131 of the Code of Administrative Procedure, the authority informs all other parties to the proceedings - regardless of whether they had appealed or not ${ }^{24}$. The next step is self-control by the authority of the first instance. According to the Art. 132 of the Code, the authority which issued the decision challenged by the appeal has the right to accept it and change the decision. The decision issued under the Art. $132 \$ 1$ and 2 of the Administrative Procedure Code may be appealed by the parties ${ }^{25}$. The first instance authority issues a new decision within seven days from the date it received the appeal. If it has not issued such a decision, it is obliged to send the appeal together with the case files to the appeal body within seven days from the date on which it received the appeal (Art. 133 of the Code of Administrative Procedure).

After the appeal is handed over, along with the case files, the second stage of the appeal procedure takes place, i.e., proceedings before a higher-level body. This procedure involves three stages:

23 Judgment of the Provincial Administrative Court in Kraków of April 25, 2019, II SA/ Kr 263/19, LEX No. 2703961.

24 D. Kałuża, M. Płoszka, R. Robaszewska, Decyzja o warunkach zabudowy, LexisNexis 2014, https://sip.lex.pl/\#/monograph/369306126/278467/kaluza-dariusz-ploszka-marcin-r obaszewska-renata-decyzja-o-warunkach-zabudowy?cm=URELATIONS (14.01.2021).

25 B. Majchrzak, op.cit., p. 203. 
- $\quad 1^{\text {st }}$ stage (Art. 134 and 135 of the Code),

- $\quad 2^{\text {nd }}$ stage - the explanatory proceedings (Art. 136 of the Code),

- $\quad 3^{\text {rd }}$ stage - issuing a decision (Art. 138 and 139 of the Code) ${ }^{26}$.

In the first phase, the second instance authority examines the admissibility of the appeal and whether the deadline for appealing has been met. Therefore, the authority should declare an appeal inadmissible where: a) specific provisions exclude the possibility of appealing against a given decision; $b$ ) the instance course has already been exhausted; c) an unauthorized person brings them ${ }^{27}$. If the body finds that the appeal is inadmissible - the higher-level body issues a decision on the inadmissibility of the appeal. As mentioned earlier, the authority also checks whether the appeal has been submitted on time. If the appellant has failed to meet the deadline, he may submit a request to the appeal body to restore the deadline. The public administration body finally has resolved this request competent to examine the appeal (Art. $59 \S 2$ of the Code). Both of these provisions, under the Art. 134 of the Code are final, and, as decisions concluding the appeal proceedings, they may be the subject of a complaint to the voivodship administrative court under the Art. $3 \$ 2$ point 2 of the Act of August 30, 2002, Law on Proceedings Before Administrative Courts ${ }^{28}$.

After examining the admissibility and the deadline for appealing, the second-instance authority must consider the case, the proceedings, and the decisions of the first-instance authority, from the perspective of legality and expediency $^{29}$.

The Supreme Administrative Court stated that the appeal body is entitled to conduct only supplementary evidentiary proceedings (Art. $136 \$ 1$ of the Code) and explanatory proceedings to the extent necessary (Art. $136 \$ 2$ of the Code). However, when there is a need to conduct explanatory proceedings in whole or in large part, the second instance authority is obliged to re-

26 Ibidem.

27 Z.R. Kmiecik., Wszczęcie ogólnego postępowania administracyjnego, LEX 2014, https:// sip.lex.pl/\#/monograph/369287704/189479/kmiecik-zbigniew-r-wszczecie-ogolnego-poste powania-administracyjnego? cm=URELATIONS (15.01.2021).

28 Dz.U. 2019, item 2325 as amend.

29 Judgment of the Supreme Administrative Court of June 24, 1998, file ref. III SA 1379/97, ONSA 1999, No. 3, item 85. 
voke the first instance authority's decision and refer the case to that authority for reconsideration. It should be added that carrying out supplementary evidence proceedings by the appellate body itself is permissible and even desirable, but only if it does not result in violation of the principle of two-instance proceedings (Art. 15 of the Code) ${ }^{30}$. It should be emphasized that the appeal body adjudicates according to the legal and factual status existing on the date of issuing its own decision ${ }^{31}$. Therefore, it is required to consider the factual and legal changes that occurred after the first instance authority issued the decision ${ }^{32}$.

The party may withdraw an appeal before the appeal body issues the decision. Written withdrawal of the appeal within the meaning of the Art. 63 of the Code is an act of submitting an application containing a declaration of will to withdraw an appeal. An effective withdrawal of an appeal is tantamount to an act of waiving the right to appeal, but this declaration must be explicit and unconditional ${ }^{33}$.

The final stage of the appeal procedure is issuing a decision under Art. 138 of the Code in which the second instance body:

1. upholds the contested decision, or

2. recalls the challenged decision in whole or part and, in this respect, rules on the merits of the case, or, repealing this decision - discontinues the first instance proceedings in whole or in part, or

3. discontinues the appeal procedure,

4. repeals the challenged decision and refers the case for reconsideration to the first instance authority, when the decision was issued in breach of the provisions of the procedure, and the scope of the case necessary for clarification has a significant impact on its resolution. When referring to the case, the authority should indicate what circumstances should be considered when reconsidering the case.

30 Judgment of the Supreme Administrative Court of October 28, 2020, file ref. II OSK 2567/20, LEX No. 3088202.

31 Judgment of the Supreme Administrative Court dated August 3, 1995, file ref. SA/Gd 435/95, OwSS 1996, No. 2 item 39.

32 Judgment of the Provincial Administrative Court in Warsaw dated March 5, 2007, file ref. VI SA/Wa 1877/06, Legalis.

33 Judgment of the Supreme Administrative Court of November 13, 2019, file ref. II OSK 2078/19, LEX No. 2778452. 
The provision contains a closed catalog of decisions of the appeal body. It means the appeal body is not entitled to issue decisions with sentences other than the mentioned ones ${ }^{34}$.

\section{Constitutional Right to Challenge Administrative Decisions to a Court}

The party has the right to appeal against the decisions issued by the second instance authority to the Administrative Court. Proceedings before administrative courts are separate from the administrative procedure. The subject of an administrative court case is not a decision on the rights or obligations arising from administrative law provisions but an assessment of the action of administrative bodies in a given case. Judicial control is subsequent, so it is admissible after the conclusion of the administrative procedure ${ }^{35}$. The judicial control of administration has been regulated in section VIII of the Constitution of the Republic of Poland, "Courts and Tribunals". Under the Art. $175 \mathrm{sec} .1$ of the Constitution, the administration of justice in the Republic of Poland is exercised by the Supreme Court, common courts, administrative courts, and military courts. Therefore, the justice system covers all cases (disputes) concerning the entity (similar entities) ${ }^{36}$.

The administrative judiciary is an element of the judiciary separate from common courts. The primary task of the administrative judiciary was formulated in Art. 184 of the Polish Constitution. Namely, it is the control of the activities of public administration. Similarly to administrative proceedings, court-administrative proceedings are two-instance, which results from the content of the Art. 176 of the Basic Law. The provision of the Art. $176 \mathrm{sec} .1$ of the Constitution has a twofold character. On the one hand, it is a systemic regulation, as it defines the manner of organizing court procedures and, consequently, the manner of organizing the court system. On the other hand, the

34 A. Wróbel, Komentarz do art. 138 kpa., [in:] Kodeks..., eds. M. Jaśkowska, M. Wilbrandt-Gotowicz, A. Wróbel, LEX/el. 2020.

35 W. Federczyk, Sądownictwo administracyjne, [in:] Postępowanie administracyjne, eds. W. Federczyk, M. Klimaszewski, B. Majchrzak, Warsaw 2013, p. 285.

36 L. Garlicki, Commentary to art. 175, [in:] Konstytucja Rzeczypospolitej Polskiej. Komentarz, vol. IV, ed. L. Garlicki, Warsaw 2005, p. 6. 
Art. $176 \mathrm{sec} .1$ of the Constitution is a guarantee provision because - complementing the provisions of the Art. 78 - specifies the content of the individual's right to two-instance court proceedings ${ }^{37}$. On the other hand, the provision of the Art. $176 \mathrm{sec} .2$ of the Constitution entrusts the ordinary legislator with determining the system of courts, their properties, and proceedings before the courts. It is also an imperative of statutory regulation, meaning that all the system's basic elements, jurisdiction, and court procedure should be defined at the statutory level. It does not preclude the legislator from referring specific matters from the scope to regulation by way of regulation. The Art. $176 \mathrm{sec} .2$ of the Constitution is therefore primarily a systemic one.

\section{Summary}

Summing up, it should be pointed out that the right to appeal against an administrative decision is a fundamental right of a party, guaranteed in the Constitution and the Code of Administrative Procedure. It allows verification of the decision by a higher instance body that seems to be professional and better prepared to deal with the case. The possibility of verifying a judgment made in the first instance is the essence of the right to appeal expressed in the Art. 78 of the Polish Constitution. Therefore, it is possible to deduce a postulate addressed to the legislator that the procedure should be shaped so that it provides (as far as possible) the right to bring an appeal by a party. The provision in question is general and included in the second chapter of the Constitution, devoted to the freedoms, rights, and obligations of a person and a citizen, regulating measures to protect freedoms and rights. It shows that it applies to both administrative and administrative court proceedings. The Constitution imposes an obligation on the legislator not only to formally authorize a party to appeal against decisions issued in the first instance but also to create legal guarantees securing the effectiveness of this measure in the sense that it should enable the second-instance body to substantively assess the correctness of the settled case.

37 L. Garlicki, Commentary to art. 176, [in:] Konstytucja Rzeczypospolitej Polskiej..., p. 25. 


\section{Literature}

Adamiak B., [in:] Kodeks postępowania administracyjnego. Komentarz, eds. B. Adamiak, J. Borkowski, Warsaw 2019.

Błaś A., [in:] Konstytucje Rzeczypospolitej oraz komentarz do Konstytucji RP z 1997 roku, ed. J. Boć, Wrocław 1998.

Czynności procesowe zawodowego petnomocnika w sprawach administracyjnych i sadowoadministracyjnych, ed. H. Knysiak-Molczyk, Warsaw 2013.

Federczyk W., Sądownictwo administracyjne, [in:] Postępowanie administracyjne, eds. W. Federczyk, M. Klimaszewski, B. Majchrzak, Warsaw 2013.

Garlicki L., Commentary to art. 175, 176, [in:] Konstytucja Rzeczypospolitej Polskiej. Komentarz, vol. IV, ed. L. Garlicki, Warsaw 2005.

Kałuża D., Płoszka M., Robaszewska R., Decyzja o warunkach zabudowy, LexisNexis 2014.

Kmieciak Z., Komentarz do art. 127, [in:] Kodeks postępowania administracyjnego. Komentarz, eds. W. Chróścielewski, Z. Kmieciak, Wolters Kluwer 2019.

Kmieciak Z., Odwołania w postępowaniu administracyjnym, Oficyna 2011.

Kmiecik Z., Dwuinstancyjność ogólnego postępowania administracyjnego w świetle przepisów Konstytucji RP i Kodeksu postępowania administracyjnego, "Annales Universitatis Mariae Curie-Skłodowska, Sectio G” 2017, vol. LXIV.

Kmiecik Z.R., Wszczęcie ogólnego postępowania administracyjnego, LEX 2014.

Knysiak-Molczyk H., Uprawnienia strony w postępowaniu administracyjnym, Zakamycze 2004.

Majchrzak B., Weryfikacja rozstrzygnięć w toku instancji, [in:] Postępowanie administracyjne, eds. W. Federczyk, M. Klimaszewski, B. Majchrzak, Warsaw 2013.

Skrzydło W., Konstytucja Rzeczypospolitej Polskiej. Komentarz do art. 78, LEX 2013.

Wojtyczek K., Prawo do skutecznego środka prawnego w Konstytucji RP, "Przegląd Konstytucyjny" 2017, No. 1.

Wróbel A., Komentarz do art. 138, [in:] Kodeks postępowania administracyjnego. Komentarz aktualizowany, eds. M. Jaśkowska, M. Wilbrandt-Gotowicz, A. Wróbel, LEX/el. 2020.

Wróbel A., Komentarz do art. 15, [in:] Kodeks postępowania administracyjnego. Komentarz aktualizowany, eds. M. Jaśkowska, M. Wilbrandt-Gotowicz, A. Wróbel, LEX/el. 2020. 